\title{
「国際水路の非航行的利用に関する条約」の 発効と衡平利用原則
}

\author{
天野 健作 1) \\ 1）東京大学大学院新領域創成科学研究科 \\ （干277-8563 柏市柏の葉 5-1-5）
}

\begin{abstract}
「国際水路の非航行的利用に関する条約」が, 国連総会での採択から 17 年を経て, 2014年 8 月に発効した.この条 約は国境をまたぐ河川，湖沼，地下水を含む淡水資源の開発や管理に関する国際基準を示したもので，国際社会に 大きな影響を及ぼすものと考えられる，特に，条文上最も重要視される「衡平利用原則」については，水資源をめ ぐる当事国間で紛争があった場合の一つの解決基準として用いられると期待され，事実，発効前にもかかわらず, これまで国際司法裁判所の判決でも引用されてきた，条約は当事国のみを規律するのが原則であるが，締約国以外 にも当該条文が適用できるか，いわゆる国際慣習法化されているかは，条約発効後の国家実行や裁判例を待つ必要 があろう.
\end{abstract}

キーワード：国際水路の非航行的利用に関する条約，衡平利用原則，国際司法裁判所，国際河川，国際慣習法

\section{I 、はじめに}

国際河川などの水資源をめぐる対立や紛争を解決 するためのメルクマールとして, 国際基準や国際法 の確立が求められている。 なぜなら，人口増大や経 済成長とともに水の需給は世界的に逼迫しており， 国家間や地域間の対立は今後ますます増えるものと 予測され，国際裁判上で解決されるのは稀ではある が, 法の下での解決が期待されるからである。すで に国際河川をめぐる紛争は顕在化しており, インダ ス川，ドナウ川，ウルグアイ川などの国際河川にお ける国家間の紛争が，国際司法裁判所や常設仲裁裁 判所に付託されてきた。紛争当事国の間に条約や協 定など個別の合意が存在すればよいが，存在しない 場合，適切な解決には限界がある。

こうした意味で, 1997年5月に国連総会で採択さ れ，2014年 8 月に発効した「国際水路の非航行的利 用に関する条約」（以下，国際水路条約）は，国際 的な水資源を扱う関係者にとって大きな影響を及ぼ すものと考えられる。この条約の本旨からして, 水 資源の持続可能な管理や衡平な分配に大きく寄与す るとともに, 紛争解決に導く「強い道具」ともなり うるからである。
国際水路条約の採択直後から，この条約を対象と した先行の研究は数多く出ている（しばしば引用さ れる文献としてMcCaffrey and Sinjela, 1998; Tanzi and Acari, 2001)。しかし, 条約採択以降すでに17年間 を経ており, 紛争解決に向けた国際水路条約の実効 性について，明確に分析されたものはそれほど多く ない.

このため本稿では, 第 1 に, この条約の対象とす る所を概説するとともに, 第2 に, 条文上とりわけ 重要とされる「衡平利用原則」が, 条約当事国以外 の関係する紛争に適用できるか, すなわち, すでに 国際慣習法化された規定になっているかについて考 察を加える。

\section{II．条約発効の経緯とその対象}

海洋資源は,「国連海洋法条約」（1982年採択, 1994年発効）が包括的に扱っているが，淡水資源 を規律する一般的・普遍的な条約は存在していな かった。国連総会は1970年, 水資源の不足が予想 されることに鑑み，その保全・保護が全国家にとっ て重要であることを強調した上で, 国際法委員会 
（International Law Commission, 以下 ILC）が国際水路 に㧍ける「法の漸進的発達」の作業に従事すること を勧告する決議を採択した（UN General Assembly， 1970）。学者や外交官ら 34 人の国際法のエキスパー トで構成されるILCは1974年に, 条約草案の作成作 業に着手し, 1994年に作業を完了させた.

条約草案は1997年 5 月, 103 力国の賛成を伴い国連 総会で採択された（UN General Assembly, 1997）。こ こでは, 中国，トルコ，ブルンジという国際河川の 上流国3力国が自国の領域主権が制限されることを 懸念し，決議に反対したことに留意すべきである. ただ,これら 3 カ国は条文に含まれる基本原則にす べて反対しているわけではなく，例えば，中国は 国際水路条約の基本原則を取り入れた協定をカザ フスタンとの間で2001年に結んでいる (Agreement between Kazakhstan and China on Cooperation in the Use and Protection of Transboundary Rivers, 2001).

条文上, 35 力国の批准（あるいは受諾, 承認, 加 入）が発効要件であり (第36条), 2014年 5 月に 35 カ国目のベトナムが批准したことで（表一1参照）, 90 日間を経て条約は発効した.

この国際水路条約の対象とする国際水路 (international watercourses) とは, 国際河川からもう 少し広い概念であり, 地表水や地下水などを含む, 「物理的な一体性」(第2条) を重視している用語で ある。

国際河川は世界に276を数え, 145 力国を流れてお

\section{表-1 国際水路条約の参加国}

Table 1 UN Watercourses Convention Participants.

\begin{tabular}{|c|c|}
\hline 国 名 & 批准年月 \\
\hline フィンランド & 1998 年 1 月 \\
\hline シリア & 1998 年 4 月 \\
\hline パラグアイ & 1998 年 8 月 \\
\hline ノルウェー & 1998 年 9 月 \\
\hline 南アフリカ & 1998 年 10 月 \\
\hline ヨルダン & 1999 年 1 月 \\
\hline レバノン & 1999 年 5 月 \\
\hline スウェーデン & 2000 年 6 月 \\
\hline イラク & 2001 年 1 月 \\
\hline オランダ & 2001 年 1 月 \\
\hline ナミビア & 2001 年 8 月 \\
\hline カタール & 2002 年 2 月 \\
\hline リビア & 2005 年 6 月 \\
\hline ポルトガル & 2005 年 6 月 \\
\hline ドイツ & 2007 年 1 月 \\
\hline ウズベキスタン & 2007 年 9 月 \\
\hline チュニジア & 2009 年 4 月 \\
\hline スペイン & 2009年 9 月 \\
\hline
\end{tabular}

り，国際水路の中心となっている。国際河川流域は 地球上の陸地の $40 \%$ 以上を占め, 世界人口の 6 割近 くは国際河川流域に住んでいると推定される。国際 水路をめぐっては 1820 年以降, 400 以上の個別国家 間の条約が結ばれたものの, 158 の国際河川で「協力 的管理メカニズム」がないとされる (Giordano and Wolf, 2002). 協力的管理メカニズムとは, 上流国や 下流国にかかわらず単一的な組織で河川の維持・管 理を目的とする体制であるが, 領域主権を部分的に でも奪われることを嫌う国家は，二国間（bilateral） だけの個別条約を結ぶ傾向にある（Zawahri and Mitchell, 2011).

二国間の枠組みを超えた包括的な規律を目的とす る国際水路条約の対象は, 名前通り, 航行を除いて おり, 農業用灌溉や飲料, 工業用水, 発電などに関 するものである，条約は全部で7つのパートから成 り, 計 37 条と条文数はそれほど多くはない. 条約は 以下のようにいくつかの権利と義務を規定している ことが特筆すべき点である.

・「水路国は，その領域に扮いて国際水路を利用する にあたり，他の水路国に重大な害を生じさせるこ とを防止するために全ての適切な措置をとる」(第 7 条)

・「水路国は, 水路の状態に関して容易に利用可能な デー夕及び情報, とりわけ水文学的, 気象学的, 水路学的及び生態学的性質の情報であって水質な らびに関連する予測に関するものを，定期的に交 換する」(第 9 条)

・「水路国は, 国際水路で計画された措置の潜在的影 響について交涉し，お互いに情報交換，協議しな ければならない」(第11条)

・「水路国は, 他国に重大な悪影響を及ぼす計画措置 を実行する前に, 関係国に事前通報しなければな らない」(第 12 条)

国際水路条約は, 起草過程での論争を反映して全 般的に妥協的性格の規定も多いと批判されている (児矢野, 2006)。逆に, 条約に規定されている規則 の多くが, 国際慣習法の一部を構成していることは 疑いない, という好意的な見方もある（山本， 2011). 特に, 妥協的性格か否か, 国際慣習法化し ているか否かという点で, 国際水路条約の中心的な 規定とされる「衡平利用原則」が, 最も議論が分か れるところである，以下，この衡平利用原則の意義 について考察する。 


\section{III. 衡平利用原則の意義}

国際河川における水資源利用原則の考え方は，(1) 絶対的領域主権論（上流国は下流国の利益を考えず に自由に水資源を利用することができる)，(2)領土 保全論（上流国は下流国の領土保全を妨げてはなら ない)，(3)制限主権論（上流国は下流国に重大な害 を及ぼさないように使用しなければならない)，(4) 流域の統合管理論（流域国内で一元的に共同管理す る）など，多岐にわたる（McIntyre, 2007；井上， 2005)。明らかなのは, 衡平利用原則は制限主権論 の一種であり, この点, 1972年の「ストックホルム 人間環境宣言」(第 21 原則) や「リ才宣言」(第 2 原 則）などでも繰り返し引用されている。ただ，実際 の水利用の国際規律は各地域における任意の協定に 委ねられていることにも留意する必要がある（波多 野, 2012).

その上で条文を見ると, 原則の一般規定として, 第 5 条には次のように規定されている.

「水路国はそれぞれの領域において国際水路を衡 平かつ合理的な方法で利用する。特に水路国は，関 係する水路国の利益を考慮しつつ, 水路の適切な保 護と両立する利用及びそこから生ずる便益を最適か つ持続可能なものとするように水路を利用し，その 開発を行う」

ここで何が「衡平」に当たるのか, 条約は批判に さらされた。衡平の具体的適用にあたっては以下に 記述するように，何通りもの解釈が可能であり，そ の概念は曖昧だからである (Wirsing et al., 2013). 特にいくつかの上流国は，下流国の利益を損なわな いように衡平義務を負うのは上流国だけであり，下 流国の方が優位だとみなし，条約には偏見があると 主張している (Salman, 2013).

条約草案作成過程でも以上のような議論が活発に なされ，第 6 条では，衡平利用は「次に掲げる事項 を含むすべての『関連する要素と事情』（relevant factors and circumstances）を考慮することを要する」 として以下のように列挙している.
（a）地理的，水理的，水文的, 気候的, 生態的その 他の自然的性質を有する要素
（b）関係する水路国の社会的及び経済的必要
(c) 各水路国における当該水路に依存している人口
（d）水路国による水路の使用が他の水路国に与える 影響
（e）水路の現在の使用及び潜在的に可能な使用

（f）水路の水資源の保全, 保護, 開発及び効率的使 用とそのためにとられる措置の費用

(g) 特定の計画中の使用又は現在の使用に準ずる価 值を有する代替策の利用可能性

しかし, これらの要素や事情についても, 実際に 適用する際には困難さが予測される。例えば，国際 水路の利用が国家の命運を握るが人口が少なく水路 の利用から生じる便益が 1 億ドルに満たない小国と， 当該水路の利用から生じる便益が 10 億ドルであり水 路に依存している人口が多い大国による利用のいず れが優先されるべきだろうか（山本, 2011)。（b）に 重きを置けば小国であるし，（c）であれば大国にな るというように解釈によってどちらにも軍配を上げ ることが可能である.

そこで具体的な紛争から衡平利用原則の適用事例 を見る。

国際司法裁判所 (International Court of Justice, 以下 ICJ）で，非航行的利用に関して国際河川をめぐる 紛争が付託されたのは, (1)「ガブチコボ・ナジュマ ロシュ計画事件」（International Court of Justice, 1997） と, (2)「ウルグアイ川パルプ工場事件」(International Court of Justice, 2010）の2件だけである.

前者はドナウ川におけるダム建設をめぐって，下 流国のハンガリーと上流国のスロバキア（旧チェコ スロバキア）が争ったケースである.1977年の両国 の条約「ガブチコボ・ナジュマロシュのダムシステ ムの建設と運用に関する条約」の下で，スロバキア がガブチコボで 720 メ゙ワットのダムを, ハンガ リーがナジュマロシュで 158 メガワットのダムを建 設する計画に合意したものの，ハンガリーは環境影 響への懸念を理由に計画を一時停止し条約の一方的 終了宣言を行った。しかし, ダム建設がほぼ終了し ていたスロバキアは, ハンガリーの一方的宣言で経 済的損失を被ったと主張し，ハンガリーは計画の停 止を求め, 両国はICJへの付託に合意した. 1997年の ICJ判決では, 環境保護を理由に条約の終了原因と は認められないとして, ハンガリーの行動を正当化 できないとした。

中でも「衡平な利用原則」について, ICJは「(ス ロバキアの開発計画は）ドナウ川の天然資源の衡平 かつ合理的な配分の権利をハンガリーから奪うこと になる」(para. 85) と判示し,「国際水路の資源の衡 平かつ合理的な配分に対する基本権」（para. 78）に も言及した。この点, 国際水路条約の起草に携わっ たマッカフリーは, この基本権は条約から派生する 
ものではなく，国際慣習法の規範となっていること を強調した上で,「裁判所が権利を『基本』と位置 付けたことは，衡平利用原則がこの分野での法の 『要石』(corner stone) となっていることの証明であ る」と指摘している（McCaffrey, 2013）.

後者のパルプ工場事件は, ウルグアイ川の下流国 であるアルゼンチンから上流国のウルグアイが建設 を計画するパルプ工場が下流に深刻な環境污染が懸 念されることから，両国が1975年に合意した「ウル グアイ川協定」に違反するとして，ICJに提訴され たものである，ICJは2010年，ウルグアイが手続的 な義務（通報義務や協議義務）に違反したものの， 実質的な義務（污染の防止，水質保全など）には違 反しないと判示した. ICJは手続違反を宣言するこ とで, アルゼンチン側の満足 (satisfaction) が得られ るとして (para. 23), 金銭賠償の請求は認めなかった.

衡平利用原則に関しては, ICJは直接的に国際水 路条約に言及していないものの,「共通の資源を有 する他の流域国の利益と環境保護を考慮しなけれ ば，そのような利用は衡平や合理的とみなすことは できない. 裁判所の意見としては, 衡平利用と, 経 済発展及び環境保護のバランスは相互に関連すると いうことである」(para. 177）と判示している。この 点, マッカフリーは国際水路条約の規定と一致する ためには, 「裁判所が, 衡平利用とは他国利益を考 慮するだけでなく，共通資源の環境を保護すること を考慮に入れなければならないことに気付いたこと は重要である」とも指摘している（McCaffrey, 2013)。しかし, 衡平利用原則は国際水路条約の規 定はあるものの，いまだ解䣋において一定の見解が 確立されていないため, 実際の紛争解決に適用する ことには慎重とならざるをえない。この判決におい ても, 衡平利用原則の趣旨や目的の説示にとどまっ たことに慎重さが現れている（鳥谷部, 2011）.

\section{IV.おわりに}

国際水路条約が発効後, いかに国際社会で適用さ れていくかは, 国際社会の主体である国家がこの条 約をどのように重要視してダム開発などに役立てて いくか, その実行を待つしかない。特に，条約に明 確な反対の意思を示した国際河川の上流国3力国が どのように振る舞うか, 注視する必要があろう。例 えば，中国はインドとの間に流れる国際河川のブラ マプトラ川で近年, ダム開発を続けて扔り下流国の
インドの反発を招いているが (Christopher, 2013), 国際水路条約に規定されているようなデー夕と情報 の定期的交換（第9条）には応じるなど, 国際社会 を意識した挙動も見せている。

また東南アジアを流れる国際河川のメコン川で も, 上流国の中国が近年, 相次いでダムを建設した ことで，下流域諸国から抗議を受けるなど，一種の 緊迫した状況にあるが, 国際機関に水文デー夕を提 供するなど協調的側面もみせている（天野, 2014）.

水の分配や国際河川をめぐる紛争の基準となる衡 平利用原則は, 国際水路条約上, 幾通りもの解釈が 可能な規定であり, 国際裁判所での引用事例も少な く, 現状では国際慣習法化したとまでは言い切れな い. しかし国際水路条約の発効が一つの大きな夕ー ニングポイントであり, 今後, 条約批准国の増加を 促し，国家実行を積み上げれば，衡平利用原則が国 際社会の普遍的な基準として定着していくことが期 待される。

\section{引用文献}

Agreement between Kazakhstan and China on Cooperation in the Use and Protection of Transboundary Rivers. 2001. http://iea.uoregon.edu/pages/view_treaty.php?t=2001UseProtectionTransboundaryRivers. EN.txt\&par=view_ treaty_html (参照:2014/7/1)

天野健作 2014. メコン川の水資源をめぐる中国と米国. 水文·水資 源学会誌27 (2) : 77-83.

Christopher, M. 2013. Water Wars: The Brahmaputra River and Sino-Indian Relations. U.S. Naval War College Case Study. http://www.usnwc.edu/getattachment/b5236b30-fce4-40ed935a-016578bc4483/Water-Wars.pdf\#search='water+war+si no+indian' (参照:2014/6/22)

Giordano M, Wolf A. 2002. The World's International Freshwater Agreements: Historical Developments and Future Opportunities in UN Environment Programme. Atlas of International Freshwater Agreements : 2-7.

波多野英治 2012. 水資源を巡る国際法の進展と課題. 環境法政 策学会誌第15号: 193-208.

井上秀典 2005. 国際水環境紛争における衡平な利用原則の検討. 人間環境論集 6 (1) : 41-52.

International Court of Justice. 1997. Case Concerning the Gabčíkovo-Nagymaros Project (Hungary v Slovakia) (Judgment) ICJ Reports 1997 : 7. http://www.icj-cij.org/docket/ files/92/7375.pdf (参照:2014/6/28)

International Court of Justice. 2010. Case Concerning Pulp Mills on the River Uruguay (Argentina v Uruguay) (Judgment) ICJ Reports $2010: 4$. http://www.icj-cij.org/docket/files/135/15877. pdf (参照:2014/6/28)

児矢野マリ 2006. 国際環境法における事前協議制度一執行手段と しての機能の展開. 有信堂: 73-74.

McCaffrey S, Sinjela M. 1998. The 1997 Uneited Nations Convention on the Law of Non-Navigational Uses of International Watercourses. American Journal of International 
Law 92-1 : 97-107.

McCaffrey S. 2013. The progressive development of international water law in Loures F, Rieu-Clarke A. The UN Watercourses Convention in Force: Strengthening international law for transboundary water management. Routledge : 10-19.

Mclntyre O. 2007. Environmental Protection of International Watercouses under International Law. Ashgate : 12-40.

Salman S. 2013. Misconceptions regarding the interpretation of the UN Watercourses Convention, in Loures F, Rieu-Clarke A. The UN Watercourses Convention in Force: Strengthening international law for transboundary water management. Routledge : 28-35.

Tanzi A, Acari M. 2001. The United Nations convention on the Law of International Watercourses. Brill.

鳥谷部壤 2011. <判例研究>国際司法裁判所 ウルグアイ河パ ルプ工場事件 (判決 2010年4月20日). 阪大法学61:583-611.

UN General Assembly. 1970. Resolution 2669 (XXV) Progressive Development and Codification of the Rules of International Law relating to International Watercourses, $1920^{\text {th }}$ Plenary Meeting (December 8, 1970). http://www.
un.org/en/ga/search/view_doc.asp?symbol=A/RES/2669\%2 8XXV\%29\&Lang=E\&Area=RESOLUTION (参照:2014/6/22)

UN General Assembly. 1997. Resolution A/RES/51/229 Convention on the law of the non-navigational uses of international watercourses, $99^{\text {th }}$ plenary meeting (May 21, 1997). http://www.un.org/en/ga/search/view_doc. asp?symbol=A/RES/51/229\&Lang=E（参照:2014/6/28)

Wirsing R, Stoll D, Jasparro C. 2013. International Conflict over Water Resources in Himalayan Asia. Palgrave Macmillan : 134-138.

山本 良 2011. 国際水路の非航行的利用における「衡平原則」の 現代的展開. 村瀬信也.鶴岡公二. 変革期の国際法委員会. 信山 社:297-317.

Zawahri N, Mitchell S. 2011. Fragmented Governance of International Rivers: Negotiating Bilateral Versus Multilateral Treaties. International Studies Quarterly 55 : 835.

（受付：2014年7月 13 日, 受理：2014年 10月9日） この論文への討議・コメントを, 2015年7月末日 まで受け付けます。

\title{
The UN Watercourses Convention in Force and the Principle of Equitable Utilization
}

\author{
Kensaku AMANO 1) \\ 1) Graduate school of Frontier Sciences, The University of Tokyo \\ (5-1-5, Kashiwanoha, Kashiwa-city, Chiba, 277-8563, JAPAN)
}

The Convention on the Law of the Non-navigational Uses of International Watercourses is to enter into force in August 2014 after adoption by the United Nations General Assembly in 1997. The convention shows international standards for the development and management of fresh water resources across the border, including rivers, lakes and groundwater. It is expected to influence international society strongly. Especially, the principle of equitable utilization is expected to be useful as a solution standard when a dispute arises between a downstream country and an upstream country on an international river. In fact, although the convention still had not entered into force, the principle was quoted in the International Court of Justice ruling. The convention in principle is to discipline only the related parties, but other rulings or state practices should be observed until it has become an international customary law.

Key words : UN Watercourses Convention, principle of equitable utilization, International Court of Justice, international river, international customary law 